\title{
СУЧАСНІ ТЕНДЕНЦІЇ РОЗВИТКУ ЖУРНАЛІСТСЬКИХ ЖАНРІВ У БЛОГОСФЕРІ
}

\author{
Мирослава Рудик \\ Львівський національний університет імені Івана Франка, \\ вул. Генерала Чупринки, 49, 79044, Львів, Україна, \\ e-mail: rudyk miroslava@ukr.net \\ https://orcid.org/0000-0003-3612-100X
}

У статті досліджено сучасні тенденції розвитку журналістських жанрів у блогах, виокремлено найпопулярніші жанри блогосфери, окреслено такі явища як трансформація та дифузія жанру, проаналізовано міжжанрові різновиди журналістських текстів.

Ключові слова: блог, інтернет-журналістика, жанр.

Розвиток сучасної блогосфери вносить чимало змін до розуміння та традиційного трактування журналістських жанрів. Жанр, як усталена форма тексту, відживає своє канонічне призначення, натомість набуває нових рис та ознак, які на нього накладає час. Так онлайнова журналістика порушила усталену систему жанрології, де панував чіткий поділ на інформаційні, аналітичні та художньо-публіцистичні жанри. Видатні журналістикознавці: Д. Григораш, В. Здоровега, О. Кузнецова, І. Михайлин, А. Москаленко, А. Тертичний, розробили критерії поділу жанрів на групи, упорядкували типологічну структуру жанрів, яка впродовж тривалого періоду характеризувалась стійкістю, стабільністю та відповідала вимогам часу.

Актуальним завданням для дослідження сьогодні є вивчення тенденцій розвитку журналістських жанрів, простеження їхнього шляху еволюції. Вважаємо, що саме блогосфера передає багаторівневу структуру жанрової системи. У блогах межі, що розділяють жанри, стають менш помітними, а мультимедійність, гіпертекстуальність та інтерактивність спонукають до розширеного сприйняття інформації, яке поєднує у собі часом кілька жанрів водночас. Враховуючи стрімкий розвиток сучасної медіасфери, технічні можливості інтернет-журналістики, важливим є дослідження сучасних журналістських жанрів не тільки для впорядкування жанрової класифікації, а задля комплексного підходу до нових жанрових можливостей та їх втілення у текстах для реалізації успішного комунікування.

Історіографія досліджуваної теми охоплює теоретичні основи поділу журналістських жанрів, представлені науковими доробками вищеназваних вчених, так i сучасні праці дослідників інтернет-журналістики. Серед них виокремлюємо Б. Потятиника, С. Квіта, М. Чабаненко, С. Шебеліста, О. Голік, І. Тонкіх, Л. Ярошенко та О. Чекмишева, Л. Шутяк.

(C) Рудик М., 2019 
Мета дослідження - простежити тенденції сучасного жанроутворення на прикладі блогової журналістики. Ми ставимо перед собою такі завдання: охарактеризувати новітні тенденції формування жанрової палітри; дослідити явища трансформації та дифузії журналістських жанрів; на прикладі блогів видання «Високий Замок» та «Gazeta.ua», простежити тенденцію зміни журналістських жанрів; з'ясувати, які чинники впливають на процес трансформації жанрів; проаналізувати створення міжжанрових різновидів журналістських текстів.

Об’єктом дослідження є блоги сайту видання «Високий Замок» та «Gazeta.ua».

Предмет дослідження - це тенденції новітнього жанроутворення у матеріалах блогерів Наталії Балюк, Іларіона Панькова, Івана Фаріона, Віталія Портникова, Людмили Малиновської, Марії Моісеєвої, Олександра Солонька, Ганни Бурлаки та ін.

Отож, під класичним визначенням жанру розуміють: «Усталений тип твору, який склався історично і відзначається особливим способом освоєння життєвого матеріалу, характеризується чіткими ознаками структури» [1, с.148].

Дослідник I. Михайлин вважає: «Категорія жанру є найбільш консервативною в журналістиці, найбільш стійко утримує сталі, вироблені в процесі історичного розвитку ознаки. Про це свідчить те, що жанрова система з паперової спокійно перекочувала в електронну журналістику. І все ж під тиском мінливої, еволюціонуючої соціальної дійсності відбувається поступове оновлення і жанрової системи в цілому, і внутрішньої конституції кожного жанру зокрема» [2, с.374].

Із стрімким розвитком мережевої журналістики все більшої популярності набувають блоги, які виокремлюються у нові авторські жанри, у них синтезуються ознаки традиційних журналістських жанрів й мультимедійних елементів. Нові медіа зазнають відчутного впливу процесів швидкого обміну інформацією, а також технологізації поширення інформації, що в багатьох випадках унеможливлює здійснити чітке та однозначне окреслення жанру.

На думку дослідниці О. Голік: «Розвиток й набуття популярності блогів дали можливість журналістам бути вільнішими у виборі форми подання матеріалу [3, с. 405]. На трансформаційні процеси у системі жанрів, на думку дослідниці, вплинули: динамічність політичних процесів - чим відкритіша політична система, тим більше інформації продукується й активніше використовуються добірки інформаційних заміток, хроніки, репортажі, інтерв’ю, коментарі, бліцопитування; ринкові умови функціонування соціальних комунікацій; розвиток Інтернету у сфері соціальних комунікацій - друковані видання потужно використовують можливості веб-сайтів, мають рубрику «Блоги»); взаємодія мас-медіа між собою; розвиток зарубіжних друкованих 3МI; вплив суміжних із журналістикою сфер людської діяльності; загальний культурний рівень аудиторії [3, с. 405].

Науковиця I. Тонкіх виокремлює тенденції, що є першопричиною трансформації жанрів у мережі. Серед них: гіпертекстуальність, інтерактивність (діалогічність, наявність зворотного зв'язку між автором та аудиторією), мультимедійність (здатність поєднувати можливість різних знакових систем - вербальних, графічних, художніх, аудіовізуальних). Дослідниця, беручи до уваги практичний сегмент цього питання, простежує той факт, що «мультимедійні формати мають жанри інформаційних та аналітичних груп: замітки, репортажі, інтервю, журналістське розслідування, статті. У блоговій та громадянській журналістиці переважають художньо-публіцистичні жанри з елементами аналітики. Говорить про зовсім новий мультимедійний 
формат - лонгрід, у якому також часто поєднані ознаки художньо-публіцистичних жанрів. Дослідниця справедливо зауважує, що блоги, які спочатку виконували лише функцію персональних електронних щоденників, зараз активно трансформуються і набувають все більшої публіцистичності й аналітичності, вони розраховані на велику кількість читачів і значний суспільний резонанс. «Окрім того, форма щоденнику дозволяє зберігати відверту суб'єктивність позиції та експресивність оціночних суджень. Тому саме блоги - як читацькі, так і журналістські - наявні майже у всіх онлайнових 3МІ» [5, с.295].

Як бачимо, жанр наділений змістово-формальною природою та складається зі сталих та змінних елементів, які пояснюють об'єктно-суб'єктний характер жанроутворення. У блоговій журналістиці виникають нові трансформовані жанри, що містять ознаки інших жанрових моделей. Втім, журналістська жанрологія збагачується новими формами завдяки взаємодії з інтернет-середовищем. А блоги стали своєрідною платформою, яка сприяє розширенню журналістського потенціалу, що знаходить своє втілення у матеріалах, а, значить, значно розширюють вже існуючі ознаки жанрів й призводять до певних різновидів та модифікацій у жанровій палітрі.

Розглянемо деякі блоги сайту видання «Високий Замок» та «Gazeta.ua». До прикладу, блог головного редактора газети «Високий Замок» Наталії Балюк. Для нього характерна насичена емоційність та авторський підхід до розкриття суспільних явищ та проблем. Журналістка застосовує прийом діалогічності, що зближує автора 3 аудиторією. Для висвітлення актуальної теми використовує елементи декількох жанрів - аналітичних та інформаційних, звичайно, є й вкраплення публіцистики. Серед її матеріалів - художні репортажі з елементами інтерв’ю, життєві історії (новий жанр, який набирає популярності у сучасній блогосфері), iï тексти не рідко містять детальні описи внутрішнього світу героїв, через які Наталія Балюк формує своє ставлення до проблеми. У своїх публікаціях вдається до всіх груп жанрів, поєднуючи публіцистику з інформаційним відтворенням дійсності. Так у матеріалі «Бомж поклав каліці гривню...» [6]. Наталія Балюк поєднала одночасно елементи репортажу, статті та есе. Від репортажу - динамізм та розкриття історії через своїх героїв, створення ефекту присутності, від статті - проблемність, аналіз, а від есе - розлогість думок, використання художніх засобів, суб’єктивізм. У цій публікації авторка порушила питання, яким люди часто нехтують, питання довіри, яким зловживають. Описала ситуацію, свідком якої була сама, і яка напрочуд її здивувала. Це історія безхатька, який сам, будучи знедоленим, допоміг каліці.

Блог Іларіона Панькова в онлайн-виданні «Високого Замку» теж характеризується поєднанням різних жанрів. Матеріли цього автора здебільшого присвячені темі інноваційних технологій, технічного прогресу людства, який не тільки приносить користь. Наприклад, публікація «Діти без дитинства» [7] за композицією, жанровою специфікою можна ідентифікувати як інформаційний текст з елементами аналітики та вираженою думкою автора. Це стаття, у якій автор порушує питання інтернет-залежності серед молодого покоління. Іларіон Паньків порушує проблему і водночас пропонує шляхи їі вирішення. Ця публікація - це синтез жанрів статті, есе та кореспонденції чи розширеної замітки.

Блог Івана Фаріона насичений авторськими роздумами про важливі суспільно-політичні проблеми чи про «добросусідські» взаємини між Україною та Угорщиною, чи заробітчанство, чи політичні загравання у спорті. Публікаціям автора 
притаманний публіцистичний стиль, емоційна аргументація, розлогість авторської думки. Щодо жанрового розмаїття публікацій, то журналіст вдало втілює інформаційні жанри, надавши їм художньо-публіцистичного забарвлення. Мова автора багата на прислів'я, приказки, яскраві порівняльні звороти, жартівливі описи та оцінки. До прикладу матеріал «Про коштовний камінь малахіт і життєві цінності заробітчанина» поєднав у собі проблемну статтю з елементами інтерв’ю та портрет. Через призму проблеми заробітчанства автор розкриває сутність свого героя публікації пана Валентина, який маючи статус громадянина Польщі стверджує: «Хоча маю «карту поляка» - з України не втечу...» [7].

Видання «Gazeta.ua» представлено блогами істориків, політологів, філософів, письменників, громадських діячів та науковців.

Так, блог публіциста Віталія Портнікова переважно містить матеріали гострополітичного характеру. Автор дає оцінку українській дійсності, політичній ситуації в країні, чимало уваги приділяє українсько-російським взаєминам. Публікація журналіста «Щоб вижити, українцям потрібно голосувати за цінності, а не за набите черево» [8] $є$ прикладом аналітичної статті з елементами публіцистичних вкраплень. Віталій Портников аналізує позицію екс-президента Чехії Вацлава Клауса щодо українсько-російських відносин, а саме відверту симпатію до Кремля. Історичний екскурс, оцінка внутрішньополітичної ситуації в Чехії аргументовано доводить, що питання економічного розвитку без урахування моральних цінностей не можуть вивести країну з кризи і позбавити корупції.

Зазвичай, автор вдається до публіцистичних жанрів, для яких характерна гострота критики, емоційність, влучні словесні образи. Однак, матеріали Віталія Портникова мають елементи інформаційних та аналітичних жанрів. Щодо тенденцій нового журналізму, то публікації автора викликають найбільший резонанс і як наслідок чимало коментарів до блогових записів.

У блозі Марії Моiсеєвої, що на сайті видання «Gazeta.ua», розміщений матеріал під заголовком «7 способів вберегти довкілля та ще й зекономити» [9]. Публікація нагадує статтю, в якій порушено проблему захисту довкілля, а саме глобального потепління, боротьба із пластиком на законодавчому рівні. Однак заголовок і сама композиція публікації є заміткою-міні-порадою.

Блог Ганни Бурлаки, тревел-блогерки, мандрівниці, відповідно, містить тематичні статті про різноманітні подорожі. Серед її контенту є матеріали, що мають властиві ознаки заміток-міні-порад, у яких авторка, опираючись на власний досвід, дає свої цінні поради й рекомендації щодо того, як правильно спланувати подорожі і зробити процес підготовки до них простішим. Використовує у матеріалах поєднання інформаційних та публіцистичних жанрів одночасно - нарисів 3 репортажним методом відтворення дійсності.

Цікавим є матеріал «Батьківські забобони, які можуть зіпсувати дитині життя» [10]. Людмила Малиновська має глибокі знання у галузі психології, тому й сам текст $\epsilon$ інформаційно насиченим. Автор з'ясовує причинно-наслідкові зв'язки, розглядає 3 погляду психології чому саме діти часто моделюють поведінку своїх батьків, і чому самі ж дорослі «нав'язують» своїм дітям певну модель поведінки, яка може суттєво вплинути на доросле життя їхніх дітей. У публікації простежується симбіоз інформаційних та аналітичних жанрів. Заголовок інтригує, намагається вплинути на читача емоційно. Такі заголовки характерні для інформаційної (новинної) журналіс- 
тики. Текст містить лід, для того, щоб зорієнтувати читача у змісті наступного тексту. Цей елемент є обов’язковим у розширених замітках. Публікація побудована на концепції логічної аргументації за допомогою індуктивного методу. Отож, за жанровим походженням - це інформаційно насичена проблемна стаття 3 публіцистичним відтворенням дійсності, яскраво вираженою думкою автора.

Розглянемо ще одну публікацію із блогу Олександра Солонька «Шизофренізація суспільства» [11]. Цей матеріал також містить ознаки аналітики та має публіцистичний стиль викладу. Автор аналізує наслідки того, як українська влада насаджує ярлики своєму суспільству. Як публіцист, Олександр Солонько прагне зворушити реципієнта, вплинути на його свідомість, проводить логічні зв'язки, органічно охоплює проблемність питання та індивідуальність підходу. Матеріал містить ознаки есе, заміток публіциста й аналітичної статті.

Блоги, що стали основною частиною нашого дослідження, ілюструють усі трансформації й сучасні тенденції, що відбуваються у медіасфері. Підкреслюють нові жанроутворення і $є$ підтвердженням неоднорідності жанрів у блогосфері, що становить науковий інтерес багатьох дослідників. Порівнюючи жанрову палітру матеріалів друкованої газети «Високий Замок» та блогів цього ж видання, можна помітити, що жанрова композиція матеріалів у друкованому виданні значно відрізняється від матеріалів у блогах. Так, жанрової модифікації зазнали й матеріали у друкованому виданні, однак це можна пояснити своєрідною внутрішньою диференціацією жанрів, також характером самого об'єкта відображення, рівнем осмислення, стилістичними засобами втілення задуму. Якщо у друкованому виданні інформацію висвітлюють, керуючись певними вимогами щодо методики роботи з тим чи іншим жанром, то у блогах ми бачимо трансформацію жанрів, розкутість автора у висловлюваннях, суб'єктивізацію, та здебільшого розповідь від першої особи однини, що робить аудиторію значно ближчою до самого автора. У друкованій версії газети «Високий Замок» визначити однорідний журналістський жанр за композицією матеріалу значно легше, на відмінну від матеріалів у блогах. Основну частину газети становлять інформаційні повідомлення у вигляді заміток, чимало також репортажів, різновидів журналістського інтерв’ю. Це дає підстави вважати, що саме блоги підсилюють нові жанроутворення, впливають на явища трансформації та дифузії жанрів. Блогінг руйнує звичні жанрові стандарти, вбираючи в себе і репліку, і коментар, i peцензію, і кореспонденцію, і репортаж, й інтерв'ю, ні на що жанрово не претендуючи, але створюючи проте передумови для активної деканонізації жанрів.

Аналізуючи тексти блогів авторів видання «Високий Замок» та «Gazeta.ua», poбимо висновок, що найбільший арсенал виражальних засобів становить група інформаційних жанрів. Популярними стають розширені замітки із репортажним методом, замітки-міні-поради, замітки-міні-рецензії, іронічні коментарі, що становлять альтернативу традиційним фейлетону чи памфлету. Кожен автор знаходить себе у кількох жанрах одночасно, застосовує той формат тексту, який якнайкраще забезпечить ефективність журналістського виступу. Адже розвиток блогової та громадянської журналістики призвели до того, що поділ творів на жанри став ще більш умовним, а процес взаємопроникнення значно посилився. Трансформація журналістських жанрів у блогосфері не має на меті зруйнувати усталені класифікації жанрів у журналістикознавсті, а навпаки стає підтвердженням того, що жанрологія в інтернет-просторі вимагає більше уваги до її вивчення у практичному контексті. 


\section{REFERENCES}

1. Здоровега В. Теорія і методика журналістської творчості: підруч. / В. Здоровега // 3-тє вид. Львів: ПАІС, 2008.

2. Михайлин I. Основи журналістики. Підручник. 5-те вид. перероб. та доп. К.: Центр учбової літератури, 2011. 496 с.

3. Голік О. Новітні тенденції жанроутворення в українській пресі на початку XXI ст. / О. Голік // Збірник праць Науково-дослідного центру періодики. 2009. Вип. 1. C. 400-412. Доступно 3: http://nbuv.gov.ua/UJRN/ZPNDZP_2009_1_31.

4. Тонкіх I. Журналістські блоги як форма впливу на громадську думку в українських Інтернет-3МI [Текст] / I. Тонкіх // Психолінгвістика : збірник наукових праць. Переяслав-Хмельницький : ФОП Лукашевич О. М., 2012. Вип. 11. С. 290-297.

5. Балюк Н. Бомж поклав каліці гривню... [Електронний ресурс] / Н. Балюк. Доступно 3: https://wz.lviv.ua/blogs/377894-bomzhpoklav-kalitsi-hryvniu

6. Паньків І. Діти без дитинства [Електронний ресурс] / I. Паньків. Доступно з: https://wz.lviv.ua/blogs/371066-dity-bez-dytynstva.

7. Фаріон I. Про коштовний камінь малахіт і життєві цінності заробітчанина [Електронний ресурс] / I. Фаріон. Доступно 3: https://wz.lviv.ua/blogs/379831-khochamaiu-kartu-poliaka-z-ukrainy-ne-vtechu

8. Портников В. Щоб вижити, українцям потрібно голосувати за цінності, а не за набите черево [Електронний ресурс] / В. Портніков. Доступно 3: https:/gazeta.ua/ blog/51134/sob-vizhiti-ukrayincyam-potribno-golosuvati-za-cinnosti-a-ne-za-nabitecherevo

9. Моісеєва М. 7 способів зберегти довкілля та ще й зекономити [Електронний pecypc] / М. Моісеєва. Режим доступу до ресурсу: https://gazeta.ua/blog/50876/7sposobiv-zberegti-dovkillya-ta-sche-j-zekonomiti.

10. Малиновська Л. Батьківські заборони, які можуть зіпсувати дитині життя [Електронний ресурс] / Л. Малиновська. Режим доступу до ресурсу: https:/gazeta.ua/ blog/50759/batkivski-zaboroni-yaki-mozhut-zipsuvati-ditinizhittya.

11. Солонько О. Шизофренізація суспільства [Електронний ресурс] / О. Солонько. Режим доступу до ресурсу: https://gazeta.ua/blog/50091/sizofrenizaciya-suspilstva 


\title{
CURRENT TRENDS IN THE DEVELOPMENT OF JOURNALISTIC GENRES IN THE BLOGOSPHERE
}

\author{
Myroslava Rudyk \\ Ivan Franko National University of Lviv, \\ Generala Chuprynky Str., 49, 79044, Lviv, Ukraine \\ e-mail: rudyk miroslava@ukr.net \\ https://orcid.org/0000-0003-3612-100X
}

The article explores current trends in the development of journalistic genres in blogs, highlights the most popular genres of the blogosphere, identifies such phenomena as transformation and diffusion of the genre, analyzes the inter-genre types of journalistic texts.

The development of the modern blogosphere makes many changes to the understanding and traditional interpretation of journalistic genres. The genre, as an established form of the text, is outliving its canonical purpose, but it acquires new features and signs that time imposes on it. So online journalism has excited the well-established system of genre, where there was a clear division into informational, analytical, and artistic-publicistic genres. As we see, the genre is endowed with a content-formal nature and consists of constant and variable elements that explain the object-subject character of genre-formation. In blog journalism, new transformed genres emerge, containing signs of other genre models. However, journalistic genre is enriched by new forms due to interaction with the Internet environment. And blogs have become a kind of platform that contributes to the expansion of journalistic potential, and is embodied in the materials, and, therefore, significantly expand the existing signs of the genres and lead to certain types and modifications in the genre palette.

Analyzing the texts of the blogs of the authors of the «Vysokyy Zamok» and «Gazeta. ua», we conclude that the largest arsenal of expressive means is a group of information genres. Each author finds himself in several genres at the same time, applies the format of the text that will better ensure the effectiveness of journalistic speech. The transformation of journalistic genres in the blogosphere is not intended to destroy the established classifications of genres in journalism, but, on the contrary, it confirms that genre in the Internet space requires more attention to studying it in a practical context.

Key words: blogger, journalism, genre. 